\title{
Detection of African swine fever virus from formalin fixed and non-fixed tissues by polymerase chain reaction
}

\author{
P. D. Luka, A. R. Jambol and B. Yakubu \\ Applied Molecular Biology Department, National Veterinary Research Institute, Vom, Plateau State, Nigeria. \\ Corresponding author: P. D. Luka, e-mail: pamluka08@gmail.com, ARJ: dtrufriend@yahoo.com, \\ BY: minitsayaks@yahoo.com \\ Received: 17-06-2014, Revised: 08-09-2014, Accepted: 11-09-2014, Published online: 13-10-2014
}

doi: 10.14202/vetworld.2014.811-815. How to cite this article: Luka PD, Jambol AR, Yakubu B (2014) Detection of African swine fever virus from formalin fixed and non-fixed tissues by polymerase chain reaction, Veterinary World 7(10): 811-815.

\begin{abstract}
Aim: Formalin fixing and paraffin embedding of tissue samples is one of the techniques for preserving the structural integrity of cells for a very long time. However, extraction and analysis of genomic material from formalin fixed tissue (FFT) remains a challenge despite numerous attempts to develop a more effective method. The success of polymerase chain reaction (PCR) depends on the quality of DNA extract.
\end{abstract}

Materials and Methods: Here we assessed the conventional method of DNA extraction from FFT for African swine fever virus (ASFV) detection. The modified conventional method gave a higher quality DNA when compared with commercially available DNA extraction kits (QIAamp ${ }^{\circledR}$ DNA Mini Kit, DNeasy ${ }^{\circledR}$ Blood and Tissue Kit, and ZR Genomic DNA ${ }^{\mathrm{TM}}$ Tissue MiniPrep).

Results: An average A260/A280 DNA purity of 0.86-1.68 and 3.22-5.32 $\mu \mathrm{g}$ DNA/mg for formalin fixed and non-fixed tissues, respectively using a conventional method. In a reproducible and three times repeat PCR, the ASFV DNA expected product size of 278 bp was obtained from the DNA extract of the conventional method but not from the DNA extract of the commercial kits.

Conclusion: The present study has demonstrated that the conventional method extracts ASFV genome better than commercial kit. In summary, the commercial kit extraction appeared not suitable to purify ASFV DNA from FFT. We, therefore, recommend that the use of the conventional method be considered for African swine fever DNA extraction from FFT.

Keyword: African swine fever, detection, formalin fixed, non-formalin fixed, polymerase chain reaction.

\section{Introduction}

African swine fever (ASF) is a viral disease of domestic and wild pigs that has continued to circulate within the pig population in Nigeria. The causative agent of the disease is ASF virus (ASFV) of the genus Asfivirus in the family Asfaviridae which is a large and complex enveloped DNA virus with a genome size ranging 170-190 kbp [1].

The typically acute form of the disease is characterized by lymphoreticular endothelial cells damage resulting in widespread hemorrhage, morbidity and mortality approaching 100\%. Sub-acute form of the disease presents loss of condition that may end in death of pigs due to complications like pneumonia. Chronic survivors may also present with stunted growth, emaciation and hemorrhagic necrosis of the skin overlying the bony protuberances, abscessation and deep ulceration [2].

The virus poses serious socio-economic problems especially in the African continent as confirmed in several reports on outbreaks in many countries [3-5]. The disease has continued to spread in Nigeria causing serious socio-economic losses $[3,6]$ therefore,

Copyright: The authors. This article is an open access article licensed under the terms of the Creative Commons Attributin License (http:// creative commons.org/licenses/by/2.0) which permits unrestricted use, distribution and reproduction in any medium, provided the work is properly cited. for a proper control measures to be put in place, both active and passive surveillance has to be in place and samples reaching the laboratory within the shortest time. Collection, storage and transport media used for delivering samples to the laboratory determines there suitability and rapid diagnosis [2].

Conventionally, laboratory diagnosis of ASF utilizes indirect ELISA, immunoblotting, direct immunofluorescence, hemadsorption test, viral isolation and polymerase chain reaction (PCR) techniques on ASF suspected samples and control via the enforcement of strict sanitary measures since vaccines are not available $[7,8]$.

Molecular based analysis has a vast application in bio-medical research especially in the utilization of stored or preserved samples. Formalin fixing and paraffin embedding of tissue samples is one of the techniques for preserving the morphological integrity of tissues for a relatively long time prior to analysis. These preserved samples are a vast repository of genetic information of interest to both biological and medical researchers especially in a situation where fresh or frozen tissues are not available $[9,10]$, or where the diagnostic integrity of such samples is compromised by poor infrastructures. However, the use of molecular DNA based techniques on formalin treated tissues has been with enormous challenges 
because of the capacity of formaldehyde to form cross links between nucleic acids and proteins that causes fragmentation of genomic material [11,12]. These fragmentations lead to the inability to amplify large molecular products by PCR $[13,14]$. To generally extract DNA from formalin fixed and paraffin embedded tissues, deparaffinization will have to be carried out to de-wax embedded tissues followed by digestion of the samples and purification. Briefly, these steps involve treatment with xylene and ethanol, proteinase $\mathrm{K}$ digestion, precipitation and recovery of total DNA [15]. Moreover the success of PCR is hinged on the quality of the DNA extract and absence of contaminants that can interfere with amplification [16]. ASF is an acute DNA viral disease of pigs with high morbidity and mortality. Molecular technique has been one of the rapid diagnostic procedures employed in the diagnosis of ASF virus.

The aim of this work was to detect ASF genome from formalin fixed tissues (FFT) and non-FFT using a conventional DNA extraction procedure and commercial kits in view of the need for a rapid and qualitative DNA extraction protocol on the type of samples submitted to the laboratory for ASF diagnosis.

\section{Materials and Methods}

\section{Formalin-fixed and non-fixed tissues}

This is a laboratory experimental study utilizing ASF positive and negative tissues retrieved from $-80^{\circ} \mathrm{C}$ ultra-low freezer of the Applied Biotechnology Department, National Veterinary Research Institute, Vom Nigeria. The samples were obtained from an outbreak in October, 2013 at Langtang South local government area of Plateau state, Nigeria. The study emanated from ASF suspected samples that were submitted to the laboratory in $10 \%$ formalin for diagnosis. As a result four ASF tissues from the 2013 outbreak: Mesenteric LNs, lungs, liver and spleen earlier diagnosed positive for ASF by PCR were used. Each of the four positive samples were divided in two (Group 1,2), each of the four tissues in Group 1 were divided in triplicates and fixed in $10 \%$ formalin for 3 days at room temperature while each of the tissues in Group 2 were also divided in triplicates but not fixed (non-fixed) giving a total 12 replicates each for fixed and non-fixed tissues respectively. A group of four samples confirmed negative for ASF was also obtained to serve as control. DNA was extracted from all samples (FFT, non-fixed neurofiblirarlly tanges [NFT] and negative tissues).

\section{Design of test/ experimental set-up}

ASF positive tissues (mesenteric LNs, lungs, liver and spleen) were retrieved and grouped into two (2, and of four samples each), formalin fixed $(n=12)$ and non-fixed $(n=12)$ and a group of four $(n=4)$ ASF negative tissue samples as a control, respectively giving a total number of 28 samples (Figure-1). DNA was extracted from the three groups using QIAamp DNA mini kit, DNeasy ${ }^{\circledR}$ blood and tissue kit and ZR

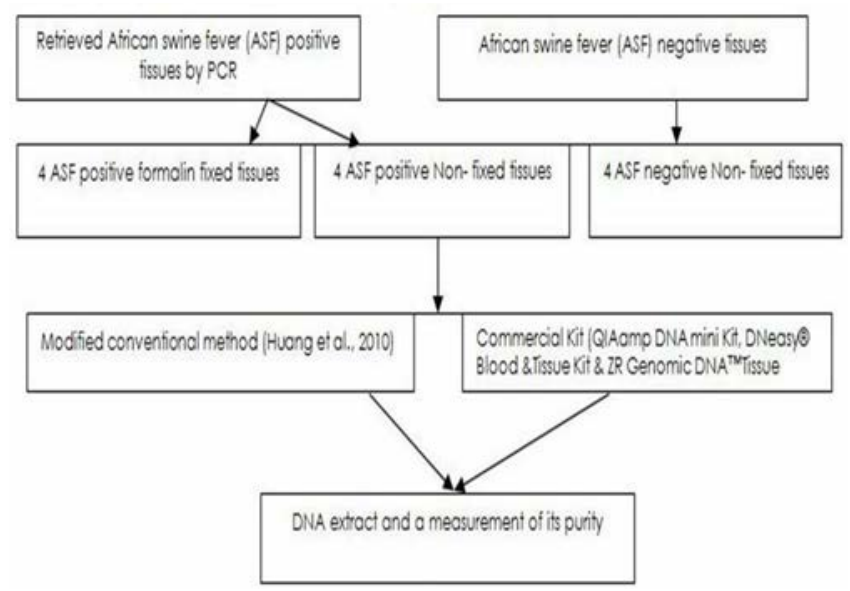

Figure-1: Study design: schematic representation of study design.

Genomic DNA $^{\mathrm{TM}}$ Tissue MiniPrep following the manufacturers' instructions and a conventional method described by Huang et al., [17] with modifications. Evaluation of the results of DNA extraction was carried out by measuring yields by spectrophotometry (BioPhotometer; Eppendorf Scientific, Hamburg, Germany) at A260/A280 and checking on 1.5\% agarose gel electrophoresis.

\section{DNA extraction from tissues}

Approximately 10-15 $\mu \mathrm{m}$ tissue snip from the total 28 (12 FFT tissues, 12 non-FFT, and 4 nonFFT negative controls, respectively) samples were put into $1.8 \mathrm{ml}$ tube and DNA extracted using the commercial kits (QIAamp DNA Mini Kit [Qiagen, Germany], DNeasy Blood and Tissue Kit [Qiagen, Germany] and ZR Genomic DNA ${ }^{\mathrm{TM}}$ Tissue MiniPrep [Zymo Research, CA, USA]) according to manufacturer's instruction. DNA was also extracted using the conventional method reported by Huang et al. [17] with some modifications. Briefly, the FFT were first washed twice in 100\%, 95\% and 75\% ethanol at $6 \mathrm{~h}$ interval after which they were also washed twice in distilled water at $6 \mathrm{~h}$ interval each. The tissues were digested overnight at $55^{\circ} \mathrm{C}$ using a total concentration of $40 \mathrm{mg} / \mathrm{ml}$ proteinase $\mathrm{K}$ added twice. DNA was extracted with phenol: Chloroform:Isoamyl alcohol (25:24:1, v/v/v) and precipitated with isopropanol and 3M sodium acetate, allowed to dry at room temperature and the resultant pellet dissolved with $50 \mu \mathrm{l}$ distilled water. Extraction was confirmed by agarose gel electrophoresis and the DNA purity measured at A260/A280 wavelength kept at $+4^{\circ} \mathrm{C}$ prior to use.

\section{Determination of DNA purity}

To assess the purity (quality) of extractedDNA, the BioPhotometer Spectrophotometer (BioPhotometer; Eppendorf Scientific, Hamburg, Germany) was used. This was necessary because amplification of genomic material depends on the quality of the product which generally varies with formalinized tissues. The experimental procedure was performed according to the manufacturer's instructions. Finally, the DNA was 
diluted twice the elution volume, and the quality evaluated by DNA amplification using the OIE pAS diagnostic primers and amplification conditions for $278 \mathrm{bp}$ product. Data obtained from the triplicate samples were analyzed using GraphPad prism version 5.00, GraphPad Software, San Diego California, USA.

\section{ASF PCR and electrophoresis}

$2 \mu \mathrm{l}$ of the DNA was used as a template for the PCR. The reaction was carried out in $200 \mu \mathrm{l}$ thinwalled PCR tubes, in a final volume of $25 \mu \mathrm{l}$ containing the following reagents: $2.5 \mu \mathrm{l}$ of $\times 10$ PCRBuffer, $2 \mu \mathrm{l} \mathrm{MgCl}(25 \mathrm{mM})$, and $0.5 \mu \mathrm{l}$ dNTPs $(10 \mathrm{mM})$, $1 \mu \mathrm{l}$ each of forward and reverse primers (20 pmol of each primer). The pAS (OIE) diagnostic primers used were pAS-1 (F), 5'-ATG GAT ACC GAG GGA ATA GC-'3; and pAS-2 (R), 5'-CTT ACC GAT GAA AAT GAT AC-‘3. PCR amplification was carried out as follows: An initial denaturation step was done at $94^{\circ} \mathrm{C}$ for $15 \mathrm{~s}$, followed by 35 cycles consisting of denaturation at $94^{\circ} \mathrm{C}$ for $15 \mathrm{~s}$, annealing at $62^{\circ} \mathrm{C}$ for $15 \mathrm{~s}$, extension at $72^{\circ} \mathrm{C}$ for $15 \mathrm{~s}$, and final extension at $72^{\circ} \mathrm{C}$ for $7 \mathrm{~min}$ for the expected products size.

The PCR products were analyzed by electrophoresis on 1.5\% agarose gel and visualized under ultraviolet light. The results were only taken as valid if all the negative controls showed no bands while the positive controls displayed bands at the 278 bp region of the DNA marker.

\section{Results}

No DNA material could be detected in agarose gel electrophoresis of the samples extracted with the three commercial kits protocol (Figure-2). Allowing the tissue to digest further for $48 \mathrm{~h}$ at an increased volume of proteinase $\mathrm{K}$ still failed to yield product amplification. However, DNA product amplification was obtained from the FFT using the Huang et al., (2010) method with some modifications (Figure-3). The quantity of DNA extract measured at $\mathrm{A}_{260} / \mathrm{A}_{280}$ ranged from 0.86 to 1.68 and 3.22-5.32 $\mu \mathrm{g} \mathrm{DNA} / \mathrm{mg}$ for formalin fixed and non-fixed tissues, respectively (Table-1). The average DNA quality of the FFT was $1.24 \mu \mathrm{g} \mathrm{DNA} / \mathrm{mg}$ compared to $4.21 \mu \mathrm{g} \mathrm{DNA} / \mathrm{mg}$ for

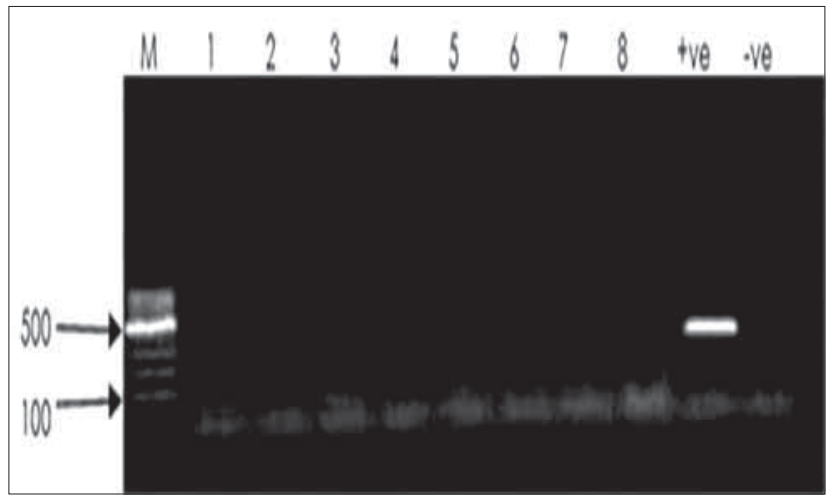

Figure-2: Gel electrophoresis showing African swine fever virus amplification: Lane $\mathrm{M}$, molecular marker of $100 \mathrm{bp}$. Lane 1-8, formalin fixed tissues DNA from commercial kits. non-fixed tissues. The modified conventional method gave higher DNA yield of 2.79 compared to the commercial kits used (Table-2) and molecular products for both fixed and non-fixed tissues on agarose gel (Figure-3).

\section{Discussion}

Diagnostic methods using DNA from FFT are becoming relevant to resolve retrospective questions from preserved tissues because of their repository genomic value. We tested African virus DNA extracts from three commercially used DNA extraction kits and a conventional method for the quality of DNA for amplification of 278 bp gene segment of ASFV by conventional PCR. The DNA obtained was diluted to eliminate or minimize the effect of PCR inhibitors but still there was no amplification for the FFT. Amplification was only obtained for samples with high DNA yield especially the non-fixed tissues. Although DNA shearing/fragmentation by formalin and the carryover of PCR inhibitors can affect amplification negatively besides, DNA was extracted and amplified [18]. Although, limited number of samples was used for the experimental study of the different commercial DNA extraction kits, but the result obtained agrees with previous field sample result of non-fixed ASF tissues by other authors [6].

The commercial kits used have been optimized and widely used for DNA isolation from samples [19-21]. DNA extracted from non-fixed tissues using the above methods yielded the expected product of $278 \mathrm{bp}$ for ASFV. This agrees with previous findings using the various kits for the detection of ASFV from suspected porcine tissues $[6,22]$. Although the sensitivities of the different commercial kits were not considered, but they have been used by different authors for the extraction of ASF suspected samples.

Using the modified conventional method of Huang et al., [17] gave high yield (purity) DNA

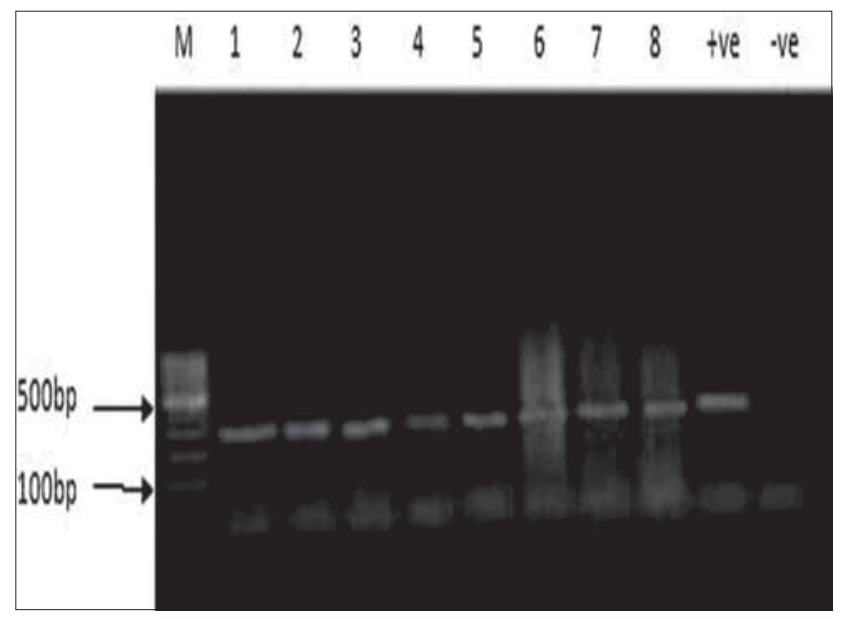

Figure-3: Polymerase chain reaction gel showing 278 bp of African swine fever virus. The first lane $M$, molecular marker of 100 bp. 1-4 non-fixed tissues and 5-8 formalin fixed tissue products from modified conventional method respectively. 
Table-1: Analytical DNA yield in mesenteric lymph node, lungs, liver and spleen, expressed as $\mu g$ DNA/mg of tissue. Fixation time of 3 days followed by conventional method extraction.

\begin{tabular}{lccccc}
\hline \multicolumn{7}{c}{ DNA yield (purity) } & mean \pm SD (n) & & \\
\hline Treatment & Mesentric LN & Lungs & Liver & Spleen & Overall \\
\hline Formalin fixed & $1.51 \pm 0.082(2)$ & $1.91 \pm 0.058(2)$ & $0.86 \pm 0.13(2)$ & $1.68 \pm 0.014(2)$ & $1.24 \pm 0.416(8)$ \\
Non-fixed & $5.32 \pm 0.123(2)$ & $3.22 \pm 0.082(2)$ & $4.11 \pm 0.018(2)$ & $4.20 \pm 0.163(2)$ & $4.21 \pm 0.860(8)$ \\
\hline
\end{tabular}

$\mathrm{SD}=$ Standard deviation, $\mathrm{LN}=$ Lymph node

Table-2: Analytical DNA yield in mesenteric lymph node, lungs, liver and spleen, express as $\mu g$ DNA/mg of tissue. Fixation time of 3 days followed by conventional method and commercial Kit extraction.

\begin{tabular}{lccccc}
\hline \multicolumn{5}{c}{ DNA yield (purity) } & mean \pm SD (n) \\
\hline Treatment & Mesenteric LN & Lungs & Liver & Spleen & Overall \\
\hline Conventional method & $3.22 \pm 0.132(3)$ & $2.30 \pm 0.072(3)$ & $2.68 \pm 0.13(3)$ & $2.96 \pm 0.014$ & $2.79 \pm 0.394(12)$ \\
QI Aamp DNA mini kit & $1.46 \pm 0.054(3)$ & $0.95 \pm 0.042(3)$ & $1.18 \pm 0.018(3)$ & $1.22 \pm 0.163(3)$ & $1.20 \pm 0.209(12)$ \\
DNeasy blood and tissue & $1.04 \pm 0.123(3)$ & $0.91 \pm 0.022(3)$ & $1.25 \pm 0.053(3)$ & $1.12 \pm 0.021(3)$ & $1.08 \pm 0.143(12)$ \\
ZR genomic DNA $^{\text {TM }}$ & $1.52 \pm 0.16(3)$ & $0.91 \pm 0.058(3)$ & $1.22 \pm 0.022(3)$ & $1.29 \pm 0.166(3)$ & $1.24 \pm 0.252(12)$ \\
\hline
\end{tabular}

$\mathrm{SD}=$ Standard deviation, $\mathrm{LN}=$ Lymph node

following prolonged washing with ethanol and proteinase $\mathrm{K}$ digestion, however, this method is laborious and time consuming and may contain residues that will affect downstream applications. These treatments yielded better results than the commercial kits suggesting that proteinase $\mathrm{K}$ treatment plays an important role in proper purification of DNA fragments. Thus the electrophoresis gel showed smears which probably corresponded to DNA degradation due to the effect of formalin. The lack of smears and bands on the commercial kit suggested the role of proteinase $\mathrm{K}$ in the tissue digestion $[13,23]$.

Although the purity of the DNA extracted was not as high as compared to NFT but the amplification yielded the desired product size for the relatively high yield. The desired amplicon size for ASFV was $278 \mathrm{bp}$, it would have been difficult if we were to amplify a product above $1 \mathrm{~kb}$ due the genome fragmentation [23]. Comparatively, the DNA yield from NFT (4.21 $\mu \mathrm{g}$ DNA/mg) was higher than those from FFT (1.24 $\mu \mathrm{g}$ DNA/mg). This may be attributed to the influence of formalin and loss of DNA during the washing steps. This is in agreement with previous report by Huijsmans et al., [24]. Our findings showed no significant differences in DNA yield among the commercial kits but significant difference with the conventional method. This differs from studies by Mirmomeni et al., [25] who reported no significant difference between phenol-chloroform method, salting out using ammonium acetate and commercial kit.

\section{Conclusion}

Extraction of DNA from formalin fixed African suspected tissues is laborious and time-consuming and the commercial kit for DNA extraction appeared not suitable to purify ASFV DNA from FFT. We, therefore, recommend that the use of the conventional method be considered for ASF DNA extraction from FFT.

\section{Authors' Contributions}

PDL and BY designed the study, and PDL drafted the manuscript while ARJ, carried out laboratory work, analyzed and all authors' interpreted the results. All authors read and approved the final manuscript.

\section{Acknowledgments}

The authors are grateful to the Executive Director, National Veterinary Research Institute, Vom, for funding the work and the Management of the department of Applied Molecular Biology for allowing this work to be carried out.

\section{Competing I nterests} interests.

The authors declare that they have no competing

\section{References}

1. Dixon, L.K., Escribano, J.M., Martins, C., Rock, D.L., Salas, M.L. and Wilinson, P.J. (2005). Asfarviridae. In: Fauquet CM, Mayo MA, Maniloff J, Desselberger U, Ball LA, editors. Virus Taxonomy, VIII ${ }^{\text {th }}$ Report of the ICTV. Elsevier/Academic Press, London (UK). p135-143.

2. Jori, F., Vial, L., Penrith, M.L., Pérez-Sánchez, R., Etter, E., Albina, E., Michaud V. and Roger, F. (2012) Review of the sylvatic cycle of African swine fever in sub-Saharan Africa and the Indian Ocean. Virus. Res., 173(1): 212-227.

3. Babalobi, O.O., Olugasa, B.O., Oluwayelu, D.O., Ijagbone, I.F., Ayoade, G.O. and Agbede, S.A. (2007) Analysis and evaluation of mortality losses of the 2001 African swine fever outbreak, Ibadan, Nigeria. Trop. Anim. Health Prod., 39(7): 533-542.

4. Gallardo, C., Anchuelo, R., Pelayo, V., Poudevigne, F., Leon, T., Nzoussi, J., Bishop, R., Pérez, C., Soler, A., Nieto, R., Martín, H. and Arias, M. (2011) African Swine fever virus p72 genotype Ix in domestic pigs, Congo, 2009. Emerg. Infect Dis., 17(8): 1556-1558.

5. Cubillos, C., Gómez-Sebastianb, S., Morenoa, N., Nunez, M.C., Mulumba-Mfumuc, L.K., Quembod, C.J., Heathe, L., Etter, E.M.C., Jori, F., Escribano, J.M. and Blanco, E. (2013) African swine fever virus serodiagnosis: A general review with a focus on the analyses of African serum samples. Virus Res., 173(1): 159-167.

6. Owolodun, O.A., Yakubu, B., Antiabong, J.F., Ogedengbe, M.E., Luka, P.D., John Audu, B., Ekong, P.S. 
and Shamaki, D. (2010) Spatio-Temporal dynamics of African swine fever outbreaks in Nigeria, 2002-2007. Transbound. Emerg. Dis., 57(5): 330-9.

7. Sánchez-Vizcaíno, M.J., Martínez-López, B., MartínezAvilés, M., Martins, C., Boinas, F., Vial, L., Michaud, V., Jori, F., Etter, E., Albina, E. and Roger, F. (2009) Scientific Report Submitted to EFSA on African Swine Fever, p1-141.

8. Gallardo, C., Soler, A., Nieto, R., Carrascosa, A.L., De Miac, G.M., Bishop R.P., Martinse, C., Fasina, F.O., Couacy-Hymman, E., Heath, L., Pelayo, V., Martı́n, E., Simon, A., Martı, R., Okurut, A.R., Lekolol, I., Okoth, E. and Arias, M. (2012) Comparative evaluation of novel African swine fever virus (ASF) antibody detection techniques derived from specific ASF viral genotypes with the OIE internationally prescribed serological tests. Vet. Microbiol., 162(1): 32-43.

9. Wandeler, P., Hoeck, P.E. and Keller, L.F. (2007) Back to the future: Museum specimens in population genetics. Trends Ecol. Evol., 22(12): 634-642.

10. Von Ahlfen, S., Missel, A., Bendrat, K. and Schlumpberger, M. (2007) Determinants of quality from FFPE samples. PLoS. One., 2(12): e1261.

11. Kayser, K., Stute, H., Lübcke, J. and Wazinski U. (1988) Rapid microwave fixation - a comparative morphometric study. Histochem. J., 20(6-7): 347-352.

12. Perlmutter, M.A., Best, C.J., Gillespie, J.W., Gathright, Y., González, S., Velasco, A., Linehan, W.M., EmmertBuck, M.R. and Chuaqui, R.F. (2004) Comparison of snap freezing versus ethanol fixation for gene expression profiling of tissue specimens. J. Mol. Diagn., 6(4): 371-377.

13. Gilbert, M.T., Haselkorn, T., Bunce, M., Sanchez, J.J., Lucas, S.B., Jewell, L.D., Van Marck, E. and Worobey, M. (2007) The isolation of nucleic acids from fixed, paraffin embedded tissues-which methods are useful when? PLOS One., 2(6): e537.

14. Gillio-Tos, A., De Marco, L., Fiano, V., Garcia-Bragado, F., Dikshit, R., Boffetta, P. and Merletti, F. (2007) Efficient DNA extraction from 25-year-old paraffin-embedded tissues: Study of 365 samples. Pathology., 39(3): 345-348.

15. Poinar, H.N. and Stankiewikz, A.B. (1999) Protein preservation and DNA retrieval from ancient tissues. Proc. Natl. Acad. Sci., 96(15): 8426-8431.

16. Lin, J., Kenedy, S.H., Svarovsky, T., Rogers, J., Kemnitz, J., $\mathrm{Xu}, \mathrm{A}$. and Zondervan, K.T. (2009) High quality genomic
DNA extraction from formalin-fixed and paraffin-embedded samples deparaffinized using mineral oil. Anal. Biochem., 395(2): 265-267.

17. Huang, W., Sheehy, T.M., Moore, L.E., Hsing, A.W. and Purdue, M.P. (2010) Simultaneous recovery of DNA and RNA from formalin-fixed paraffin-embedded tissue and application in epidemiologic studies. Cancer Epidemiol. Biomarkers. Prev., 19(4): 973-7.

18. Campos, P.F., Thomas, M. and Gilbert, P. (2012) DNA extraction from formalin-fixed material. Methods Mol. Biol., 840: 81-85.

19. Giammarioli, M., Gallardo, C., Oggiano, A., Iscaro, C., Nieto, R., Pellegrini, C., Dei Giudici, S., Arias, M. and De Mia, G.M. (2011) Genetic characterization of African swine fever viruses from recent and historical outbreaks in Sardinia (1978-2009). Virus Genes., 42(3): 377-387.

20. Koidl, C., Bozic, M., Hadzisejdic, I., Grahovac, M., Grahovac, B., Kranewitter, W., Marth, E. and Kessler, H.H. (2008) Comparison of molecular assays for detection and typing of human papillomavirus. Am. J. Obstet. Gynecol., 199(2): 144

21. Klaassen, C.H., Prinsen, C.F., De Valk, H.A., Horrevorts, A.M., Jeunink, M.A. and Thunnissen, F.B. (2004) DNA microarray format for detection and subtyping of human papillomavirus. J. Clin. Microbiol., 42(5): 2152-2160.

22. Atuhaire, D.K., Afayoa, M., Ochwo, S., Mwesigwa, S., Okuni, J.B., Olaho-Mukani, W. and Ojok, L. (2013) Molecular characterization and phylogenetic study of African swine fever isolates from recent outbreaks in Uganda (2010-2013). Virol. J., 10: 247.

23. Cao, W., Hashibe, M., Rao, J.Y., Morgenstern, H. and Zhang, Z.F. (2003) Comparison of methods for DNA extraction from paraffin-embedded tissues and buccal cells. Cancer Detect. Prev., 27(5): 397-404.

24. Huijsmans, C.J.J., Damen, J., Van Der Linden J.C., Savelkoul, P.H.M. and Hermans, M.H.A. (2010) Comparative analysis of four methods to extract DNAfrom paraffin-embedded tissues: Effect on downstream molecular applications. BMC Res. Notes., 3: 239.

25. Mirmomeni, H.M., Sujjadi Majd, S., Sisakhtnezhad, S. and Doranegard, F. (2010) Comparison of the three methods for the extraction of paraffin-embedded tissues. J. Biol. Sci., 10(3): 261-266. 